\title{
DAMPAK BISNIS ONLINE TERHADAP SOSIAL-EKONOMI DAN KARAKTERISTIK RUANG DALAM RUMAH TINGGAL DI CIBADUYUT, KOTA BANDUNG
}

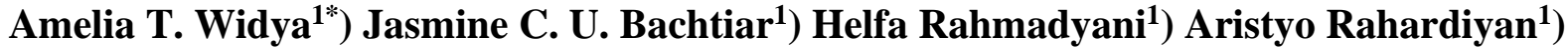 \\ Theodorus Ananda B. ${ }^{1}$ ) Agustinus A. Abadi²)
}

*)) Corresponding author email : ameliatriwidya@gmail.com

1) Magister Arsitektur, SAPPK, Institut Teknologi Bandung

2) Kelompok Keahlian Perumahan dan Perkotaan, SAPPK, Institut Teknologi Bandung

Article info

MODUL vol 20 no 02 , issues period 2020

Doi : :10.14710/mdl.20.1.2020.98-110

Received : 26 april 2020

Revised : 2 juli 2020

Accepted : 12 agustus 2020

\begin{abstract}
Abstrak
Revolusi industri 4.0 yang diinisiasi oleh perkembangan teknologi informasi digital mendorong perkembangan dalam segala bidang termasuk industri komersial. Penerapan teknologi ini berimplikasi pada perubahan pola kegiatan jual-beli secara 'online' tanpa adanya batasan jarak, waktu, dan tempat. Peluang kegiatan jual-beli 'online' tersebut dimanfaatkan oleh sebagian orang di rumah. Perubahan kegiatan ini telah berimplikasi pada perubahan sosial-ekonomi dan karakteristik fisik ruang dalam. Penelitian ini bertujuan untuk mengidentifikasi perubahan sosial-ekonomi dan karakteristik fisik ruang dalam rumah tinggal akibat kegiatan bisnis 'online'. Penelitian dilakukan di Sentra Kerajinan Sepatu Cibaduyut, Kota Bandung pada tiga studi kasus yang memiliki bisnis usaha kerajinan sepatu. Penelitian ini menggunakan pendekatan kualitatif dan pengambilan data yang dilakukan melalui observasi, wawancara, dan survei. Hasil penelitian menunjukkan adanya perubahan sosial-ekonomi dan fisik yang meliputi transformasi fungsi ruang, volume ruang, 'layout' ruang, pertumbuhan dan pembagian ruang, dan zonasi ruang. Perubahan kegiatan dengan mereduksi peran ruang "display" berimplikasi pada perubahan 'layout', pertumbuhan ruang, pengurangan volume ruang, dan perubahan fungsi ruang. Produksi yang besar mendorong ekspansi ruang produksi dengan tatanan ruang yang lebih baik melalui pembagian ruang-ruang dengan dinding partisi. Perubahan tersebut menggeser ruang-ruang dengan zona privat/semi-publik menjadi zona servis. Pengurangan
\end{abstract}

rak 'display' dan penambahan mesin produksi ditemukan mempengaruhi perubahan 'layout' ruang. Sementara itu perubahan kegiatan pemasaran 'online' dengan jumlah pesanan yang banyak menuntut perubahan fungsi ruang dengan kebutuhan ruang baru seperti ruang administrasi ruang, ruang kemas (packing), gudang penyimpanan bahan baku,, dan ruang penyimpanan barang. Hasil penelitian ini diharapkan dapat digunakan oleh arsitek atau pengembang perumahan untuk mempertimbangkan pola perilaku dan kebutuhan para pelaku industri dalam rumah tinggal di era industri 4.0 .

Keywords: Bisnis online; ruang dalam rumah; rumah tinggal; transformasi fisik; transformasi sosial-ekonomi

\section{PENDAHULUAN}

Dunia virtual didorong oleh ekonomi global; kebijakan dan politik; kepentingan dan keberagaman populasi; dan perkembangan teknologi informasi (Chidambaram \& Zigurs, 2001; pg.10) Perkembangan teknologi terus berkembang hingga sampai saat ini berada pada tahap Revolusi Industri (RI) 4.0. RI tersebut pertama kali diperkenalkan pada tahun 2011 di Jerman sebagai konsep kebijakan ekonomi berdasarkan pada strategi teknologi termutakhir (Mosconi, 2015). RI 4.0 meliputi cyber-physical systems, Internet of things (IoT), dan Internet of services. Konsep tersebut juga mendorong interaksi dan pertukaran informasi dengan penggunaan internet sesama manusia, sesama mesin, dan manusia-mesin (Roblek et al., 2016).

Perkembangan revolusi 4.0 mempengaruhi segala aspek, seperti halnya layanan akomodasi online, transportasi online, dan perdagangan online (mobil, rumah, baju, sepatu, dan sebagainya). Selain itu, perkembangan ini juga mendorong perubahan sosial- 
ekonomi atau fenomena disruptif (Prasetyo \& Trisyanti, 2018) melalui penyetaran status sosial. Semua golongan masyarakat dengan tingkat ekonomi berbeda berkesempatan untuk memperbaiki kemampuan finansialnya melalui teknologi informasi digital.

Fenomena yang dapat diamati beberapa tahun belakangan sebagai akibat perkembangan informasi digital yaitu tutupnya gerai toko konvensional (offline) karena tidak mampu bersaing dengan toko online (online shop). Berdasarkan temuan penelitian oleh (Burke, 2001), bisnis dengan mengandalkan teknologi atau online dapat meningkatkan pengalaman berbelanja bagi konsumen karena dapat menghemat waktu, mudah digunakan, dan menjawab kebutuhan konsumen dengan cepat. Selain itu, transaksi online tersebut dapat dilakukan tanpa adanya batasan jarak, waktu, dan tempat (Chidambaram \& Zigurs, 2001; pg.14) sehingga cara berdagang online lebih banyak dipilih yang telah mempengaruhi perilaku dan kegiatan yang mendukung transaksi jual-beli.

Di saat yang bersamaan, peluang kegiatan jualbeli online tersebut dimanfaatkan oleh sebagian orang yang melakukannya di rumah. Rumah yang dulunya hanya berfungsi sebagai hunian tempat tinggal, kini dituntut dapat memfasilitasi kegiatan transaksi jual-beli yang dilakukan. Kondisi ini juga pernah dialami pada masa sebelumnya, saat rumah berubah menjadi rumah toko yang mengakibatkan perubahan fungsi dan bentuk ruang (Herdiansyah, 2016). Dalam hal ini, peneliti memiliki praduga bahwa perubahan kegiatan tersebut berimplikasi pada perubahan sosial-ekonomi dan karakteristik bangunan khususnya ruang dalam rumah.

Transformasi fisik hunian merupakan salah satu strategi adaptasi berhuni. Douglas (2006) mengklasifikasikan transformasi fisik pada bangunan komersial menjadi 6 (enam), yaitu: 1) transformasi minor berupa peningkatan kualitas ruangan seperti dekorasi interior dan pencahayaan; 2) transformasi utilitas seperti perbaikan pipa; 3) transformasi struktural berupa penambahan struktur pendukung; 4) transformasi major yang melibatkan perubahan besar pada interior, transformasi minor, dan perbaikan utilitas. Akan tetapi, transformasi major tidak disertai dengan perubahan struktur; 5) transformasi secara keseluruhan yang meliputi transformasi struktural yang disertasi dengan transformasi minor lainnya; dan 6) membangun bangunan baru. Sementara itu, Omar et al. (2017) menemukan transformasi ruang dalam meliputi perluasan, penambahan, pengurangan, pembagian, dan penghapusan ruang dalam. Watson (2009) juga mengamati perubahan fisik pada tata ruang dalam yang meliputi 1) konversi (Conversion): kegiatan perubahan fungsi atau perubahan penggunaan; 2) perluasan (Extension): kegiatan yang mencakup peningkatan ukuran, baik ekspansi ruang secara horizontal maupun vertikal; dan 3) perbaikan (Refurbishment): kegiatan yang berkaitan dengan perubahan kinerja.

Penelitian terkait transformasi rumah akibat kegiatan jual-beli (komersial) telah dilakukan sebelumnya. Purnamasari et al. (2010) mengungkap transformasi pada rumah tinggal kolonial di Kota Malang. Dalam penelitiannya, transformasi fisik meliputi penambahan, perluasan, pembagian ruang, serta perubahan fungsi dan layout ruang. Sementara itu, Kellett \& Tipple (2002) menemukan perubahan ruang berupa perluasan ruang dan pemindahan tata letak perabot. Perubahan-perubahan tersebut dilakukan oleh penghuni rumah berdasarkan tingkat pengetahuan, pandangan, serta pengalaman seseorang yang berusaha untuk menyesuaikan diri dengan lingkungan dan zamannya (Erdiono et al., 2012) .

Perubahan ruang rumah tinggal dipengaruhi oleh pola pelayanan, jenis barang yang dijual, dan sistem penjualan. Perubahan ini mengakibatkan adanya perubahan pembagian zona di dalam hunian. Area hunian dimanfaatkan untuk area kerja, gudang, kantor, dan sebagainya dalam kasus ruko (Erdiono et al., 2012). Hal ini mengakibatkan ruang-ruang di dalam hunian memiliki bias fungsi antara area untuk kegiatan berhuni dan bekerja (Soegiono et al., 2011). Di rumah-toko, ruang-ruang seharusnya terbagi menjadi empat bagian yaitu zona privat (PR), semi publik (S-PB), publik (PB), dan servis (SR) (Marlina, 2018). Area privat yang digunakan untuk kamar tidur, area semi publik untuk berkumpul keluarga, area publik untuk menerima pelanggan, dan area servis untuk gudang penyimpanan. Akan tetapi, rumah yang tidak didesain sebelumnya untuk ruko menyebabkan penghuni harus beradaptasi dengan penambahan kegiatan tersebut. Mereka harus menyesuaikan dengan perubahan fleksibilitas ruang dan pergeseran nilai di dalam rumah (Soegiono et al., 2011).

Penelitian sebelumnya mengungkap transformasi ruang dalam akibat kegiatan komersial yang umumnya dilakukan secara konvensional (offline). Sementara itu, penelitian terkait pengaruh bisnis online terhadap sosial ekonomi dan karakteristik rumah tinggal masih terbatas. Dengan demikian, penelitian bertujuan untuk mengetahui perubahan akibat kegiatan berdagang online shop baik dalam sosial-ekonomi maupun karakteristik fisik ruang dalam rumah tinggal penjual online shop. Penelitian ini dilakukan untuk dapat mengisi kekosongan pengetahuan yang ada. Hasil penelitian ini diharapkan dapat digunakan oleh arsitek atau pengembang untuk mempertimbangkan pola perilaku dan kebutuhan para pelaku industri terhadap rumah tinggal di era industri 4.0.

\section{BAHAN DAN METODE}

Penelitian yang dilakukan adalah penelitian yang bersifat kualitatif dengan teknik eksploratif yaitu dengan 
melihat semua data yang ada di lapangan dengan bekal ilmu yang memadai sebelumnya (Kumar, 2005). Pada penelitian sebelumnya (Dewi \& Soesanto, 2005; Kellett \& Tipple, 2002; Purnamasari et al., 2010; Wibisono, 2013), penelitian menggunakan beberapa kasus sebagai pendekatan untuk mengungkap transformasi yang terjadi. Penelitian dengan kasus (study case) dilakukan untuk memberi gambaran tentang perkembangan, fenomena, dan kenyataan yang terjadi (Kumar, 2005). Penelitian ini menggunakan beberapa kasus (orang maupun objek) yang dianggap mampu menjelaskan dan menjawab tujuan penelitian (purposive sample). Hasil temuan dari beberapa kasus merupakan generalisasi dari pola-pola tipikal suatu objek (Wibisono, 2013). Dengan demikian, peneliti meninjau beberapa kasus dalam melaksanakan penelitian ini.

\section{Lokasi Penelitian}

Lokasi studi kasus berada di Kelurahan Cibaduyut, Kecamatan Bojongloa Kidul, Kota Bandung (Gambar 1). Kelurahan Cibaduyut merupakan sentra kerajinan sepatu di Kota Bandung. Lokasi tersebut memiliki beberapa pengrajin menjual sepatunya secara konvensional maupun online sehingga dapat menjawab tujuan penelitian yang ingin diungkap.

Perkembangan yang lumayan signifikan dari tahun ke tahun membuat sentra kerajinan sepatu Cibaduyut mampu bertahan dari para pesaing dan selalu mengikuti zaman. Banyak dari para pengrajin sepatu di kawasan Cibaduyut memanfaatkan online shop sebagai salah satu cara alternatif dalam memasarkan produknya. Hal tersebut telah memberikan banyak perubahan dalam sosial-ekonomi, berupa omzet yang meroket dan perubahan karakter penjualan. Hal ini mungkin akan berdampak pada perubahan kegiatan yang merujuk pada perubahan ruang dalam rumah. Selain itu, beberapa pengrajin sepatu masih menggunakan cara konvensional (offline) sebagai kegiatan bisnis utama karena sudah memiliki jaringan yang kuat dan luas dengan konsumen langganan. Akan tetapi, di dalam penelitian ini, responden yang dipilih adalah pengrajin sepatu yang memanfaatkan fasilitas online shop selain berjualan secara konvensional.

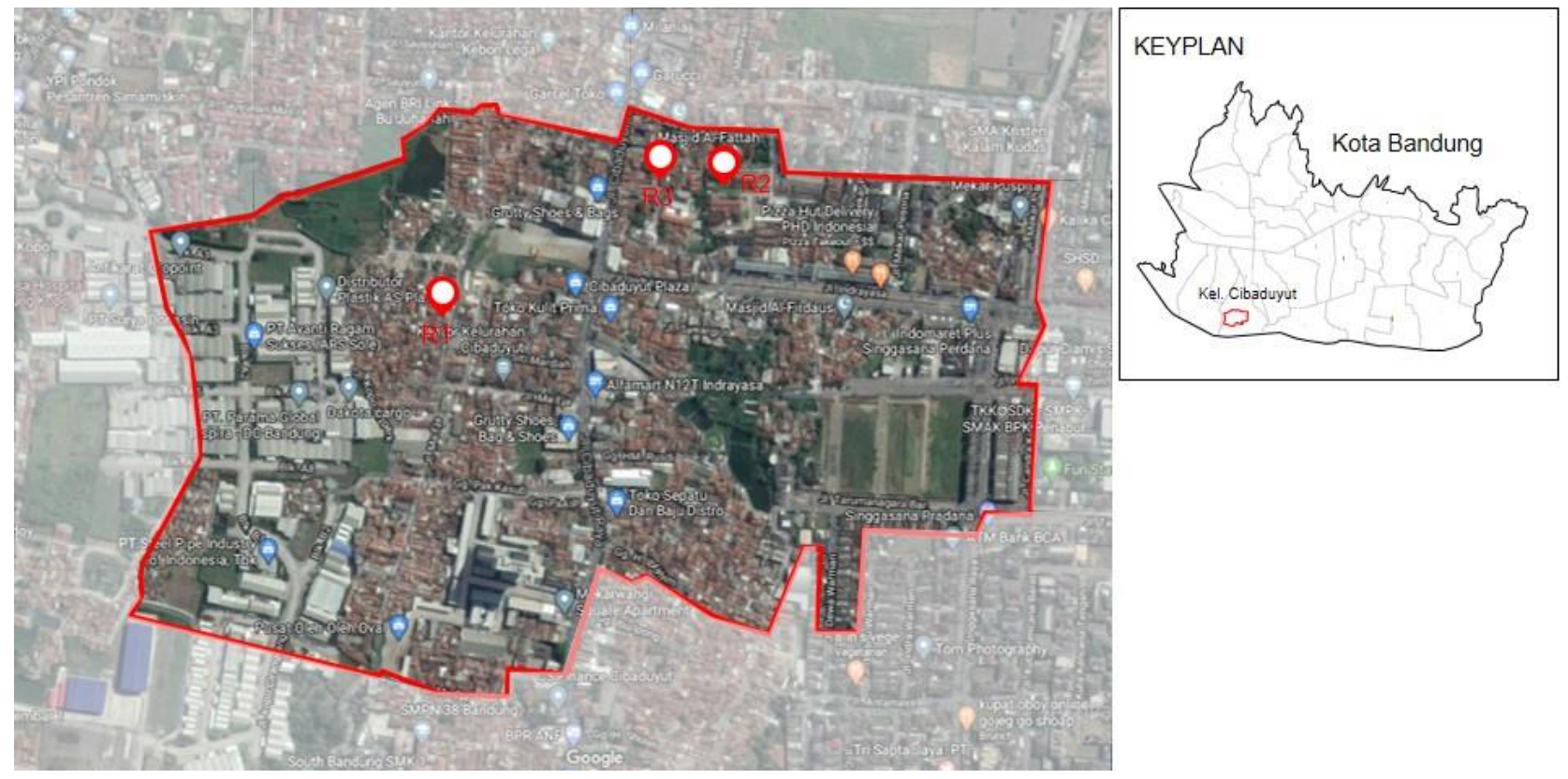

Gambar 1. Peta lokasi penelitian (Penulis, 2019)

\section{Metode Pengumpulan Data}

Pengumpulan data berupa demografi responden, jenis kegiatan online shop, perubahan kegiatan, perubahan sosial-ekonomi dan karakteristik ruang dalam rumah, serta wujud perubahan fisiknya dilakukan secara observasi, wawancara, dan survei. Karakteristik ruang didasarkan pada kegunaan dan kegiatan pada ruang tersebut (Pujantara, 2014). Hasil dari observasi dan survei berupa denah, sedangkan wawancara dengan responden akan melengkapi data perubahan karakteristik ruang dalam rumah. Responden penelitian merupakan pelaku reseller atau produsen utama dari online shop yang menyimpan barang jualannya di dalam rumah tinggalnya. Adapun kriteria responden yang menjadi contoh kasus dalam penelitian, yaitu:

1. Responden yang sebelumnya menjual produk secara konvensional (offline) dan sekarang menjual produk secara konvensional maupun 
online;

2. Responden tinggal di rumah milik pribadi;

3. Responden merupakan produsen tangan pertama;

4. Responden menjual produknya kepada penjual online lainnya namun pengiriman tetap dilakukan secara langsung oleh responden melalui ekspedisi.

Rumah pemilik bisnis online yang dijadikan sebagai kasus dalam penelitian terdiri dari 3 (tiga) orang. Kegiatan bisnis yang dilakukan yaitu menjual berbagai jenis sepatu. Responden melakukan kegiatan bisnis secara konvensional maupun online (Tabel 1).

Tabel 1. Data diri responden (Penulis, 2019)

\begin{tabular}{llllc}
\hline \multirow{2}{*}{ No. } & $\begin{array}{c}\text { Nama } \\
\text { Pemilik }\end{array}$ & Nama Toko & \multicolumn{2}{c}{$\begin{array}{c}\text { Mulai Bisnis } \\
\text { (Tahun) }\end{array}$} \\
\cline { 4 - 5 } & & Offline & Online \\
\hline R1 & Bu Kokoi & Sepatu Kokoi & 2007 & 2011 \\
R2 & Bu Prita & Narista & 2006 & 2014 \\
R3 & $\begin{array}{l}\text { Pak } \\
\text { Suhanda }\end{array}$ & Sepatu Linda & 1990 & 2011 \\
\hline
\end{tabular}

Responden yang berbeda mungkin akan memiliki nilai (value) yang berbeda pula dalam merespon perubahan kegiatan jual-beli dari konvensional ke online. Perbedaan ini disebabkan oleh nilai privasi yang dimiliki setiap orang. Seseorang mungkin akan memisahkan rumah tinggal dengan ruang etalase (display) pada masa bangunan yang berbeda karena membutuhkan privasi lebih. Akan tetapi, mungkin saja orang lain tidak membutuhkan pemisahan bangunan/ruang tersebut. Dalam penelitian ini, peneliti memilih responden yang menggabungkan fungsi rumah tinggal sebagai hunian sekaligus ruang display (bukan dua bangunan yang berbeda). Hal ini dilakukan untuk mengungkap tujuan penelitian.

\section{Metode Analisis Data}

Analisis data dilakukan dengan membandingkan antara perubahan ruang dalam berdasarkan jenis kegiatan yang dilakukan penjual. Data-data yang diperlukan berupa gambar denah sebelum dan setelah pemilik menjalankan bisnis online shop di rumah. Gambar denah tersebut kemudian dibandingkan untuk melihat perubahan karakteristik ruang dalam.

Metode analisis ini sudah pernah dilakukan sebelumnya untuk melihat perubahan karakteristik rumah yang dijadikan rumah-toko (ruko) di area pecinan (Dewi \& Antariksa, 2005). Penelitian ini akan menggunakan jenis metode yang sama yaitu metode kualitatif deskriptif.

\section{HASIL DAN DISKUSI Perubahan Kegiatan}

Di kawasan Cibaduyut, proses penjualan sepatu secara konvensional (offline) dan online sangat berbeda. Hal ini mengakibatkan adanya perubahan pola kegiatan pemilik usaha. Sebelum adanya kegiatan bisnis online, pemilik usaha berjualan secara konvensional, yaitu sepatu diproduksi dalam jumlah besar dan penjual harus menyimpan persediaan banyak sepatu untuk dipajang di etalase toko mereka. Proses jual-beli terjadi secara langsung di toko penjual. Kegiatan penjualan secara konvensional mengharuskan penjual memiliki modal awal yang besar karena sepatu harus diproduksi terlebih dahulu dengan berbagai model dengan jumlah yang banyak. Berdasarkan penelitian terdahulu, Freathy \& Calderwood (2020) menemukan bahwa penjualan produk online mengizinkan calon konsumen memilih produk dari berbagai toko sesuai dengan kebutuhan dan tidak jarang harga yang ditawarkan lebih murah dibandingkan dengan toko konvensional.

Penjualan secara online memiliki proses yang berbeda dengan konvensional yang menunjukkan perubahan kegiatan bisnis. Proses jual-beli yang terjadi dilakukan secara online dan penjual tidak memproduksi sepatu dalam jumlah besar. Kegiatan dimulai dari penjual mempromosikan sepatunya secara online di media sosial. Jika pembeli ingin melakukan pemesanan, mereka diminta untuk memesan (pre-order) sekaligus membayar pesanan dan penjual akan memproduksi sepatu sesuai pesanan pembeli. Setelah sepatu selesai diproduksi, kegiatan selanjutnya yaitu pengemasan barang untuk dikirim ke alamat pembeli melalui ekspedisi. Kegiatan tambahan yang terjadi akibat penjualan secara online yaitu seperti kegiatan pengemasan barang, mencetak nama dan alamat, dan pengiriman barang akan membutuhkan ruangan kerja tambahan. Perbedaan kegiatan jual-beli konvensional dan online dapat dilihat pada Gambar 2. 

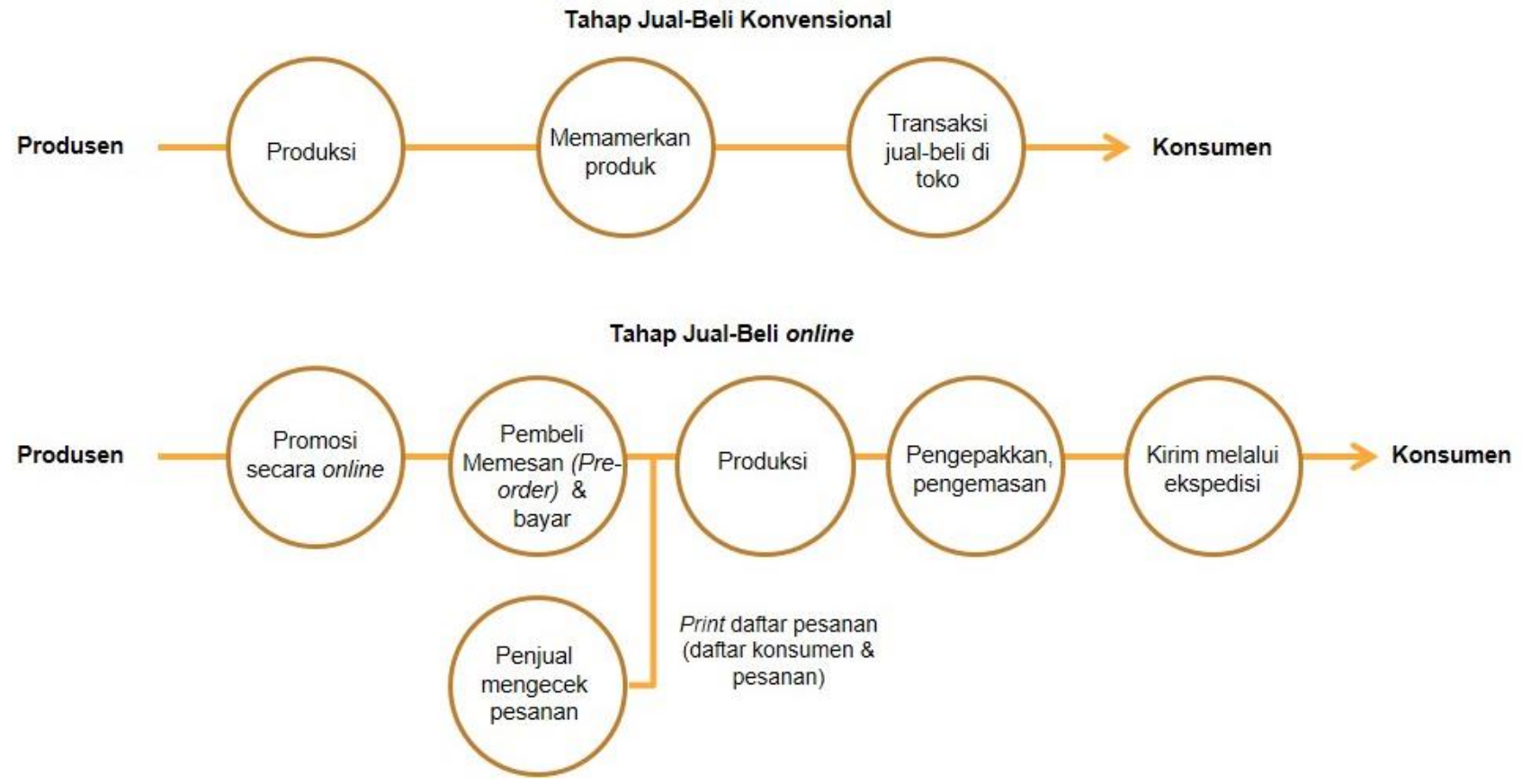

Gambar 2. Perbedaan kegiatan jual-beli konvensional dan online (Penulis, 2019)

\section{Perubahan Sosial-Ekonomi Penjual}

Penjualan sepatu secara konvensional dan online di Cibaduyut menyebabkan perubahan sosial-ekonomi. Berdasarkan hasil wawancara, kegiatan bisnis online memiliki pengaruh yang signifikan terhadap omzet penjualan sepatu. Penjualan secara online dinilai lebih menguntungkan dibandingkan dengan konvensional karena proses penjualan yang tidak mengharuskan penjual memproduksi sepatu dalam jumlah besar. Sepatu diproduksi sesuai dengan jumlah pesanan setelah pembeli melakukan pembayaran, sehingga sistem produksi dan penjualan menjadi sangat efisien. Hal ini menyebabkan beberapa responden juga memiliki peran sebagai dropshipper. Dropshipper adalah istilah yang digunakan untuk produsen tangan pertama yang melakukan pengiriman barang atas nama reseller atau penjual online. RI 4.0 menyebabkan produsen sepatu memiliki banyak peran penting dalam distribusi barang.

Penjualan secara online mampu mendorong dan meningkatkan sosial-ekonomi penjual karena luasnya jaringan pemasaran produk. Dalam penelitiannya, Freathy \& Calderwood (2020) menemukan bahwa ecommerce dapat mengembalikan keseimbangan bekerja dan membantu penduduk pulau di Skotlandia mengembangkan perekonomian yang selama ini mengalami hambatan karena keterbatasan transportasi, infrastruktur, serta kesenjangan spasial. Selain itu, taraf hidup penduduk meningkat seiring dengan berkurangnya waktu yang dulunya diperlukan untuk belanja (menyebrangi pulau). Dengan e-commerce, penduduk memanfaatkan waktu tersebut untuk berlibur. Selain itu,
(Chan et al., 2017). menemukan bahwa perkembangan e-commerce menciptakan peluang yang sama (seimbang) bagi kota dan desa. Banyak ditemukan area pedesaan menjadi sebagai pusat perputaran modal mengingat lahan dan tenaga kerja yang murah, seperti desa Taobao di Cina (Lin, 2018).

Kelurahan Cibaduyut dari dahulu sudah dikenal sebagai industri kreatif sepatu di Bandung dengan harga yang murah dan kualitas yang baik. Adanya online shop menyebabkan semakin banyaknya reseller dan penjual online shop dari berbagai belahan Indonesia yang ingin membeli dan memesan produk mereka sehingga omzet penjual semakin meningkat. Hal ini menyebabkan kebutuhan akan produksi yang semakin tinggi. Peran penjual dan pengrajin sepatu akan semakin dibutuhkan di era Industri 4.0. RI 4.0 menyebabkan jangkauan pasar penjualan sepatu yang semakin luas, yang dulunya hanya dapat dijangkau dengan kunjungan ke toko/gerai di Cibaduyut tempat menjual sepatu, kini dapat dilakukan dengan pemesanan di rumah masing-masing tanpa ada batasan jarak, waktu, dan tempat. Perpindahan dari lingkungan belanja konvensional ke belanja online menunjukkan bahwa internet merupakan peluang untuk mobilisasi virtual (Freathy \& Calderwood, 2020).

\section{Perubahan Ruang Dalam Rumah}

Perubahan kegiatan akibat bisnis online menyebabkan perubahan karakteristik fisik ruang dalam pada rumah tinggal. Perubahan tersebut dapat dilihat dari tiga contoh kasus yang telah ditinjau secara 
mendalam oleh peneliti di Kawasan Sentra Kerajinan Sepatu Cibaduyut.

\section{Kasus Rumah Tinggal 1}

Studi kasus 1 (Gambar 3) adalah rumah tinggal yang telah diubah sepenuhnya menjadi rumah produksi sepatu. Rumah produksi ini menghasilkan ratusan pasang sepatu dalam sebulan, baik pada saat membuka bisnis konvensional maupun online shop. Hal ini disebabkan dalam prosesnya, penjual menerima pesanan secara online dari pemilik bisnis barang yang sama dan kemudian penjual mengirimkan hasil produksi ke pembeli atas nama pebisnis tersebut (dropshipping). Tidak ada waktu tertentu untuk mengirimkan barang produksi.

Di dalam pelaksanaannya, beberapa bahan baku (sol sepatu) disimpan di ruang tamu rumah penjual untuk sementara waktu. Hal ini disebabkan oleh banyaknya barang akibat pemesanan online yang banyak di rumah produksi. Saat masih konvensional, penyimpanan bahan baku hanya di rumah produksi. Hal ini menunjukkan adanya fleksibilitas ruang dari ruang tamu menjadi tempat penyimpanan bahan baku.

Beberapa perubahan ruang terlihat pada rumah penjual. Saat bisnis konvensional, rumah produksi (lantai 1) dan rumah tinggal (lantai 2) masih dalam 1 bangunan yang sama. Akibat bisnis online, rumah produksi dan rumah tinggal terpisah, sehingga penjual menjadikan rumah ini hanya untuk rumah produksi saja.

Transformasi fisik yang terjadi berupa perubahan fungsi dapur di lantai 1 menjadi ruang penyimpanan barang. Ruang kamar tidur di lantai 2 beralih fungsi menjadi ruang administrasi untuk mencetak foto sesuai dengan pesanan yang masuk. Area ruang tamu di lantai 2 juga berubah menjadi ruang produksi (untuk pengemasan, jahit, dan sebagainya). Selain itu, juga terjadi penambahan volume ruang untuk tempat istirahat pekerja. Jumlah perabot mesin jahit juga mengalami penambahan yang awalnya 1 buah menjadi 3 buah, sehingga penataan ruang juga berubah.

Zonasi ruang juga mengalami perubahan. Pada gambar dapat terlihat bahwa di lantai 2, zona privat (ruang tidur) berubah menjadi zona servis (ruang penyimpanan barang) dan zona semi publik (ruang tamu dan balkon) juga berubah menjadi zona servis (workshop jahit). Hal ini menunjukkan bahwa dengan adanya kegiatan bisnis online,, sebagian besar ruang mengalami perubahan zonasi kei zona servis untuk keperluan produksi. Berdasarkan penjelasan tersebut, maka transformasi fisik yang terjadi pada rumah tinggal kasus 1 akibat bisnis online yaitu perubahan fungsi ruang, perubahan volume ruang, perubahan penataan ruang dan perubahan zonasi ruang.

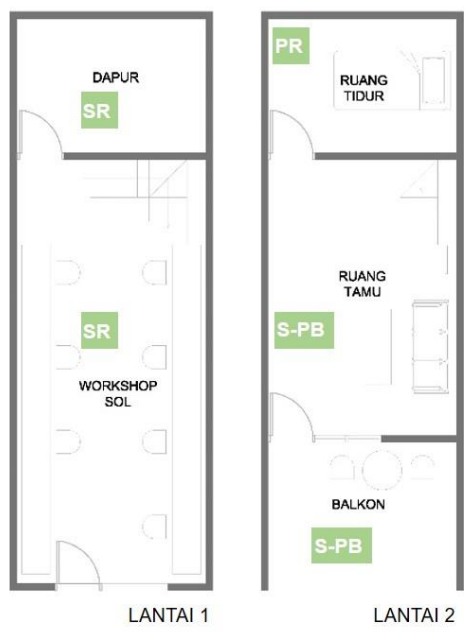

Denah sebelum transformasi
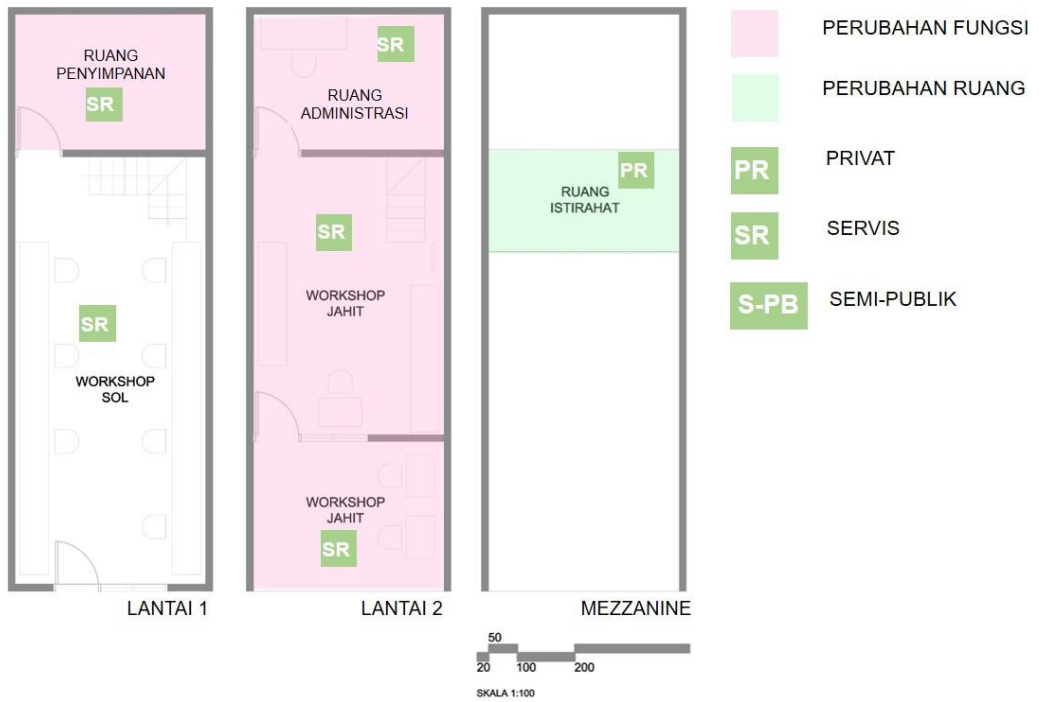

Denah setelah transformasi

Gambar 3. Transformasi fisik ruang dalam rumah tinggal pada kasus pertama (Penulis, 2019)

\section{Kasus Rumah Tinggal 2}

Studi kasus 2 menunjukkan pola kegiatan produksi yang berbeda dengan sebelumnya. Secara konvensional, penjual memiliki toko resmi di jalan utama Cibaduyut, akan tetapi toko tersebut dipindah ke rumah tinggal yang berada di dalam gang. Proses pemesanan online dapat dilakukan melalui pre-order barang yang diinginkan oleh konsumen berdasarkan 
produk pameran ataupun Instagram, lalu pemesanan akan dibuat oleh pengrajin. Setelah pembuatan selesai, barang akan dikirimkan melalui ekspedisi tanpa ada waktu atau jam tertentu pengiriman barang.

Dalam menjalankan bisnis, area depan rumah dibagi menjadi dua yaitu area display toko dan ruang tamu. Kedua area ini dipisahkan oleh sekat saat toko masih menggunakan sistem konvensional. Kebutuhan rak dan lemari untuk display juga banyak sehingga kedua ruangan harus dipisahkan agar terlihat rapi. Setelah sistem berubah menjadi online, area display tidak terlalu penting dan kebutuhan ruang tamu yang besar mengakibatkan sekat diantara keduanya dihilangkan (Gambar 4). Hal ini menunjukkan fleksibilitas ruang depan yang dapat berfungsi sebagai ruang tamu dan ruang display secara bersamaan.

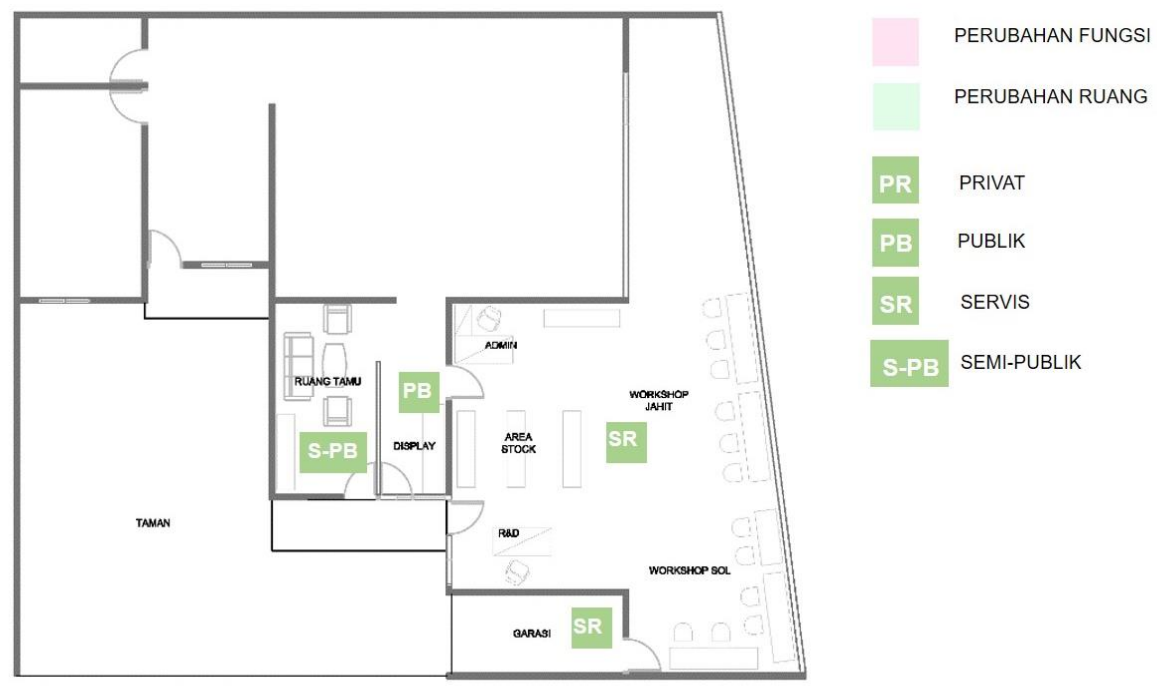

Denah sebelum transformasi

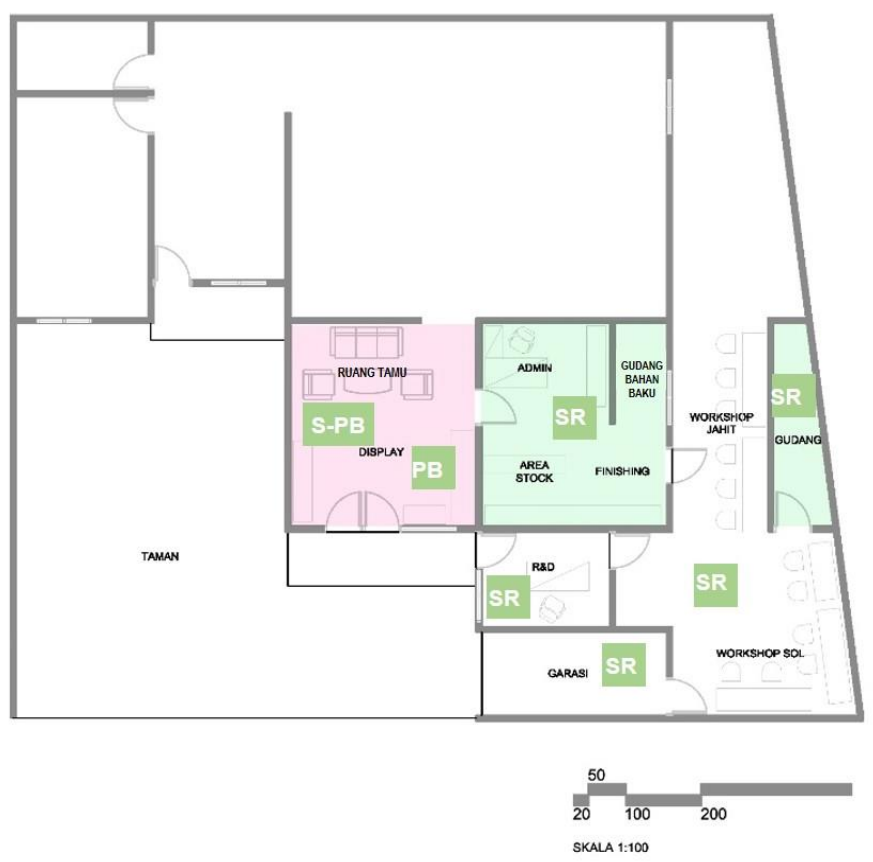

Denah setelah transformasi

Gambar 4. Transformasi fisik ruang dalam rumah tinggal pada kasus kedua (Penulis, 2019) 
Beberapa perubahan ruang terlihat pada kasus 2 . Saat bisnis konvensional, semua kegiatan produksi dilakukan di satu area tanpa ada penyekat untuk setiap kegiatan. Hal ini menyebabkan area penyimpanan barang, area administrasi, area workshop, dan sebagainya menjadi satu dan tidak teratur. Akibat perkembangan bisnis online, terjadi pertumbuhan dan pembagian ruang. Pertumbuhan ruang berupa pembongkaran partisi antara ruang tamu dan display agar ruang tamu menjadi lebih luas karena ruang display tidak terlalu penting dalam sistem penjualan secara online, sehingga perabot di ruang display menjadi berkurang. Kemudian terjadi pembagian ruang dengan memberi partisi atau sekat pada ruang produksi agar ruang produksi menjadi lebih tertata. Selain itu, juga terjadi penambahan volume ruang pada gudang bahan baku dan ruang penyimpanan barang, serta pengurangan volume ruang pada ruang display. Berdasarkan penjelasan tersebut, maka transformasi fisik yang terjadi pada rumah tinggal ini akibat bisnis online shop yaitu pertumbuhan dan pembagian ruang, dan perubahan volume ruang berupa pengurangan dan penambahan ruang.

\section{Kasus Rumah Tinggal 3}

Studi kasus 3 mengalami perubahan proses produksi barang dari konvensional ke online. Secara konvensional, kasus 3 harus memiliki beberapa model untuk dipamerkan dan harus memiliki banyak persediaan barang di gudang. Setelah menjadi online, produksi barang disesuaikan tergantung pesanan konsumen, sehingga tidak banyak barang yang tersisa dan modal yang dikeluarkan juga sesuai dengan estimasi biaya. Untuk pengiriman barang, tidak ada waktu tertentu yang digunakan sebagai batasan pengiriman.

Dalam proses perubahan sistem konvensional menjadi online, proses produksi barang menjadi berubah. Dahulu, produksi barang dilakukan di area belakang dekat tempat penyimpanan barang dan area depan digunakan untuk memamerkan hasil produk. Setelah menjadi online, area display sudah tidak diperlukan lagi sehingga area produksi pindah ke area depan bersamaan dengan area finishing, pengemasan (packing), dan sebagainya. Sementara area belakang digunakan untuk gudang bahan baku. Fleksibilitas ruang akibat perubahan sistem bisnis terlihat pada kasus 3 (Gambar 5).

Pada kasus 3, terjadi perubahan fungsi ruang kamar tidur pada lantai 2 menjadi ruang pengemasan. Peralihan fungsi menyebabkan kamar tidur dipindahkan ke lantai 1 , sehingga terjadinya penambahan volume ruang pada kamar tidur dan pengurangan volume ruang keluarga. Selain itu, ruang penyimpanan barang di lantai 2 juga mengalami penambahan ruang. Perubahan volume ruang berupa pengurangan ruang juga terjadi pada ruang display, selain itu ruang display juga beralih fungsi untuk kegiatan produksi, dan menerima tamu ataupun konsumen.

Kasus ini juga mengalami perubahan zonasi ruang. Pada gambar dapat terlihat bahwa di lantai 1, zona semi publik (ruang keluarga) berubah menjadi zona privat dan semi publik (kamar tidur dan ruang keluarga) karena terjadi pengalihan fungsi kamar tidur dari lantai 2 ke lantai 1. Selain itu, zona publik (ruang display) berubah menjadi zona servis (ruang produksi). Pada lantai 2, zona privat (kamar tidur) berubah menjadi zona servis (ruang pengemasan atau packing). Selanjutnya, zona semi publik (ruang santai) berubah menjadi zona semi publik dan servis (ruang santai dan ruang penyimpanan barang) karena terjadi penambahan ruang di lantai 2. Hal ini menunjukkan bahwa dengan adanya kegiatan bisnis online shop, sebagian besar ruang mengalami perubahan zonasi menjadi zona servis untuk keperluan produksi. Berdasarkan penjelasan tersebut, maka transformasi fisik yang terjadi pada rumah tinggal ini akibat bisnis online shop yaitu perubahan fungsi ruang, perubahan volume ruang berupa penambahan dan pengurangan ruang, serta perubahan zonasi ruang.

\section{Kesimpulan Perubahan Ruang Dalam}

Secara garis besar, ketiga studi kasus tersebut memiliki kesamaan dan perbedaan dalam menanggapi proses penjualan yang berubah dari konvensional menjadi online. Berdasarkan ulasan dan analisis tersebut, perubahan karakteristik ruang dalam yang terjadi ada lima, yaitu perubahan fungsi ruang, perubahan volume ruang, pertumbuhan dan pembagian ruang, penataan ruang dan perubahan zonasi ruang.

\section{Perubahan fungsi ruang}

Perubahan fungsi ruang adalah semua ruang yang dialihfungsikan dari ruang-ruang untuk hunian menjadi ruang-ruang untuk kerja. Perubahan ini terjadi di semua kasus studi. Salah satu contohnya yaitu rumah yang dahulu sebagai hunian dan produksi memiliki fungsi tambahan sebagai ruang display pada kasus 2 . Sementara itu, area ruang tidur menjadi ruang administrasi pada kasus 1 dan juga area display menjadi area produksi pada kasus 3 . Hal ini menunjukkan bahwa kebutuhan untuk memajang atau memamerkan hasil produksi pada bisnis online shop tidak terlalu penting sehingga ruang ini mengalami perubahan.

Adanya perubahan fungsi mengakibatkan penghuni rumah harus beradaptasi dengan perubahan fungsi ruang hunian yang semakin bias dengan fungsi ruang kerja (Soegiono et al., 2011). Online shop memberikan dampak pada perubahan fungsi ruang terutama pada ruang penyimpanan. Selain itu, fungsi ruang display tampak tidak menjadi prioritas lagi di ketiga kasus. 

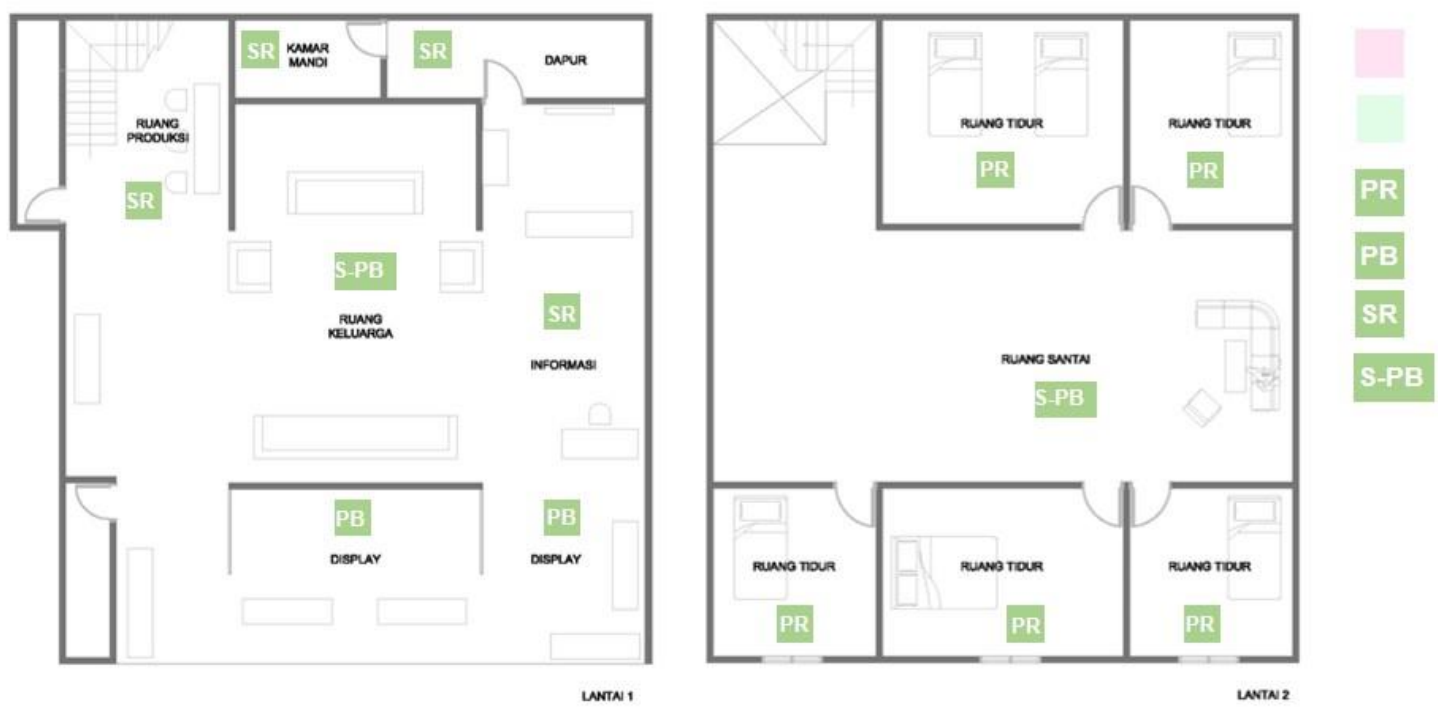

PERUBAHAN FUNGSI

PERUBAHAN RUANG

PRIVAT

PUBLIK

SERVIS

SEMI-PUBLIK

Denah sebelum transformasi

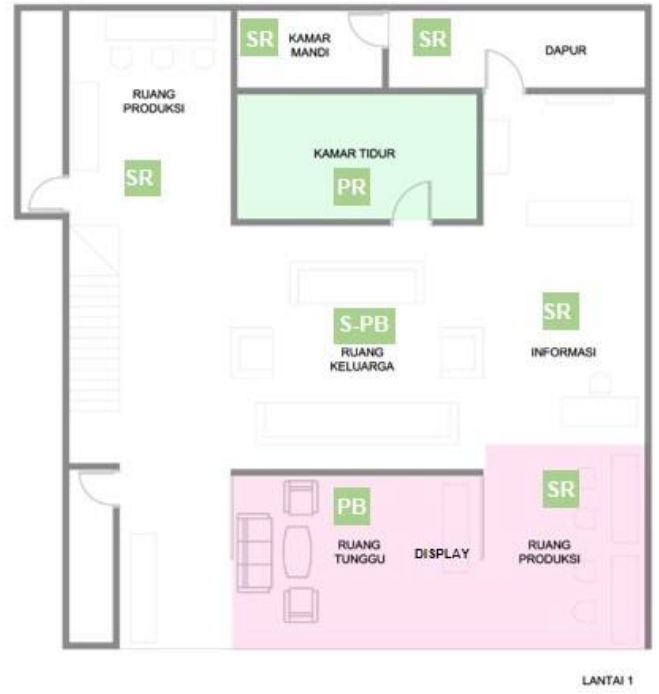

Denah setelah transformasi

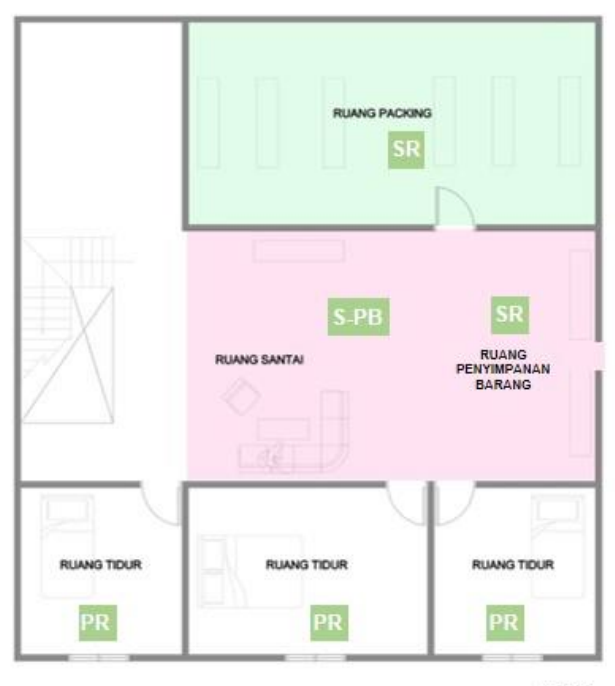

UNTN2

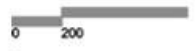

Gambar 5. Transformasi fisik ruang dalam rumah tinggal pada kasus ketiga (Penulis, 2019)

\section{Perubahan volume ruang}

Penambahan ruang banyak terjadi di ketiga kasus akibat kegiatan bisnis online yang tidak sama dengan kegiatan bisnis konvensional. Penambahan tersebut dilakukan dengan penambahan partisi ruangan sehingga layout ruang dalam berubah. Seperti kasus 3, ruang barang menjadi penting sehingga area ruang santai dibagi untuk mewadahi kegiatan tersebut. Pada kasus 1, terjadi penambahan ruang istirahat di lantai tiga akibat peralihan fungsi ruang tidur menjadi ruang administrasi di lantai dua. Selain itu, kasus 2 juga menambah ruang untuk gudang bahan baku yang sebelumnya tidak dilakukan ketika bisnis konvensional. Penambahan volume ruang secara fisik dilakukan karena adanya peralihan fungsi pada ruang lainnya dan penambahan kegiatan bisnis.

Pengurangan ruang hanya terjadi apabila kebutuhan ruang tersebut semakin kecil dibandingkan ruang lainnya. Seperti halnya dengan ruang display di kasus 2 yang sebelumnya memiliki luas sama dengan 
ruang tamu kini menjadi seperempat bagian. Selain itu, ruang keluarga pada kasus 3 juga mengalami pengurangan akibat kebutuhan ruang tidur tambahan. Kebutuhan ruang tidur ini diakibatkan oleh perubahan ruang tidur di lantai dua untuk area servis (area kerja).

\section{Pertumbuhan dan pembagian ruang}

Pertumbuhan ruang dilakukan dengan menghilangkan perabot ruangan agar ruang tersebut memiliki area yang lebih besar. Pada kasus 2, ruang tamu dan ruang display dahulu diberi sekat pembatas namun saat ini sekat tersebut dihilangkan. Penghilangan sekat dibuat agar ruang tamu lebih luas tanpa ada batas antar ruang tamu dan ruang display. Pengurangan ruang display secara tidak langsung terjadi karena tidak ada pembatas lagi. Sementara itu, penataan ruangan terlihat juga pada kasus 3 yaitu dengan penambahan sekat-sekat antar ruang di dalam ruang kerja. Penyekatan ini ditujukan untuk menata ruang produksi berdasarkan kegiatan sehingga terlihat lebih teratur.

\section{Penataan ruang}

Penataan ruang dapat dilakukan dengan pemindahan perabot ruangan sehingga antar ruangan dibatasi oleh sekat tidak permanen. Perabot dapat dipindahkan untuk penataan ruang yang baik di semua kasus. Pada kasus 1, penambahan 2 buah mesin jahit membuat area produksi semakin penuh dan padat sehingga tidak ada batasan yang jelas antar ruang setiap jenis kegiatan produksi. Pada kasus 2, responden memiliki lebih dari 5 rak untuk memasarkan produk namun saat ini rak tersebut berkurang dan tidak digunakan seperti pada awal pemakaian. Sementara pada kasus 3, peletakan mesin jahit dari area belakang menjadi berada di area depan karena kebutuhan gudang tambahan di area belakang.

\section{Perubahan zonasi ruang}

Perubahan zona ruang diakibatkan oleh adanya perubahan alih fungsi ruang yang terjadi di ketiga kasus studi. Akan tetapi, hanya kasus 1 dan 3 saja yang mengalami perubahan zona ruang sementara kasus 2 memiliki perubahan fungsi namun tidak mengubah zona ruang. Perubahan ini banyak ditemukan di kasus 3, yaitu pada ruang display (PB) yang berubah fungsinya menjadi ruang produksi, pengemasan, dan komputer (SR); kamar tidur (PR) untuk area pengemasan barang (SR); dan sebagainya. Selain itu, ada juga perubahan layout ruang yang menyebabkan perubahan zona, seperti area keluarga (S-PB) yang kemudian dibagi menjadi ruang keluarga (S-PB) dan kamar tidur (PR) sebagai akibat dari pengalihan dua kamar tidur untuk area servis (kasus 3). Perubahan ini menunjukkan luas area untuk hunian dikurangi untuk kepentingan bisnis (Erdiono et al., 2012) sehingga penghuni harus beradaptasi dengan berbagai perubahan tersebut (Soegiono et al., 2011).

Perubahan fisik yang ditemukan pada penelitian ini jika ditinjau dengan hasil temuan Douglas (2006), merupakan transformasi fisik major, yang melibatkan perubahan besar pada interior ruangan. Secara keseluruhan temuan sejalan dengan temuan sebelumnya (Omar et al., 2017; Watson, 2009) meskipun memiliki perbedaan konteks penggerak transformasi. Sementara itu, Omar et al. (2017) menemukan bahwa penghuni yang tinggal pada rumah deret (terrace house) di Lembah Klang, Malaysia melakukan penyesuaian kebutuhan dengan melakukan perluasan, penambahan, pengurangan, pembagian, dan penghapusan ruang dalam. Akan tetapi Omar et al. (2017) tidak menemukan perubahan fungsi seperti yang ditemukan Herdiansyah (2016) dan Watson (2009). Penelitian ini juga melengkapi hasil temuan keduanya. Hasil analisis menunjukkan adanya perubahan zona ruang yang belum ditemukan pada penelitian sebelumnya (Douglas, 2006; Omar et al., 2017; Watson, 2009)

Dari ketiga kasus tersebut, dapat disimpulkan bahwa kegiatan bisnis online dapat mempengaruhi aspek sosial-ekonomi maupun fisik berupa karakteristik ruang. Perubahan fisik ruang terjadi karena terdapat kebutuhan ruang yang berbeda antara kegiatan bisnis secara konvensional dan secara online. Pada penelitian sebelumnya, Burke (2001), mengidentifikasi perbedaan kebutuhan konsumen yang harus dipenuhi oleh penjual secara konvensional dan online. Temuan penelitian tersebut mengungkapkan bahwa bisnis online mengharuskan penjual untuk memberi informasi produk secara detail dan mengelola akun online untuk bisa diakses calon pembeli selama 24 jam. Selain itu, kegiatan pengemasan perlu dilakukan sebaik mungkin untuk memastikan produk terkirim dengan kondisi baik. Dari hasil temuan tersebut, kegiatan bisnis online menuntut adanya ruang administrasi untuk mengelola akun bisnis, ruang pengemasan barang, dan ruang penyimpanan barang. Penyediaan ruang-ruang tersebut ditunjukkan agar manajemen pengelolaan online shop terorganisir dengan baik.

Untuk mempermudah pemahaman terhadap perubahan karakteristik ruang dalam akibat kegiatan online, berdasarkan ketiga kasus yang telah diamati, peneliti membuat tabulasi perubahan yang terjadi (Tabel 2). Perubahan yang tersebut didasarkan atas jenis kegiatan yang dilakukan oleh responden pada ruangruang dalam rumah. 
Tabel 2. Perubahan sosial-ekonomi dan fisik akibat bisnis online (Penulis, 2019)

\begin{tabular}{|c|c|c|c|}
\hline \multirow{2}{*}{ No } & \multirow{2}{*}{$\begin{array}{c}\text { Penambahan Kegiatan } \\
\text { Akibat bisnis online }\end{array}$} & \multicolumn{2}{|c|}{ Perubahan } \\
\hline & & Sosial-Ekonomi & Fisik \\
\hline 1 & Pengepakan barang & ( & $\begin{array}{l}\text { Perubahan fungsi ruang menjadi ruang } \\
\text { untuk pengemasan barang (packing) }\end{array}$ \\
\hline \multirow[t]{2}{*}{2} & \multirow[t]{2}{*}{$\begin{array}{l}\text { Pencetakan nama dan } \\
\text { alamat pembeli }\end{array}$} & \multirow[t]{2}{*}{-} & $\begin{array}{l}\text { Perubahan fungsi ruang menjadi ruang } \\
\text { administrasi berisi komputer dan printer }\end{array}$ \\
\hline & & & Perubahan zona ruang dari privat ke servis \\
\hline \multirow[t]{5}{*}{3} & \multirow[t]{5}{*}{$\begin{array}{l}\text { Produksi sepatu sesuai } \\
\text { pesanan saja }\end{array}$} & \multirow[t]{5}{*}{$\begin{array}{l}\text { Penjualan menjadi efisien dan tidak } \\
\text { menyebabkan kelebihan stok }\end{array}$} & $\begin{array}{l}\text { Ruang display berubah fungsi menjadi } \\
\text { ruang produksi }\end{array}$ \\
\hline & & & $\begin{array}{l}\text { Pengurangan volume (ukuran ruang display } \\
\text { yang diperkecil) }\end{array}$ \\
\hline & & & $\begin{array}{l}\text { Pengurangan area display dengan } \\
\text { pembongkaran sekat ruang dinding pemisah } \\
\text { pada ruang display untuk menjadikan ruang } \\
\text { tamu lebih lapang }\end{array}$ \\
\hline & & & Perubahan zona ruang dari publik ke servis \\
\hline & & & $\begin{array}{l}\text { Perubahan layout ruang dengan } \\
\text { pengurangan perabot (seperti rak sepatu } \\
\text { atau display) dan penambahan perabot } \\
\text { (seperti mesin jahit) }\end{array}$ \\
\hline \multirow[t]{3}{*}{4} & \multirow[t]{3}{*}{$\begin{array}{l}\text { Pengiriman barang } \\
\text { secara dropship }\end{array}$} & \multirow[t]{3}{*}{$\begin{array}{l}\text { Jaringan pemasaran menjadi sangat } \\
\text { luas dan meningkatnya permintaan } \\
\text { produksi }\end{array}$} & $\begin{array}{l}\text { Penambahan ruang berupa ruang } \\
\text { penyimpanan barang, gudang bahan baku, } \\
\text { dan ruang pengemasan barang (packing) }\end{array}$ \\
\hline & & & $\begin{array}{l}\text { Perubahan zona privat ke servis (ruang } \\
\text { produksi) }\end{array}$ \\
\hline & & & $\begin{array}{l}\text { Pembangunan sekat pada ruang produksi } \\
\text { agar lebih tertata }\end{array}$ \\
\hline
\end{tabular}

\section{SIMPULAN}

Bisnis online yang dilakukan di rumah mempengaruhi perubahan kegiatan jual-beli yang berimplikasi pada keadaan sosial-ekonomi maupun fisik khususnya ruang dalam rumah. Dalam hal ini, perkembangan informasi digital mendorong penyetaraan status sosial dari semua golongan masyarakat. Setiap orang dengan tingkat ekonomi berbeda mempunyai kesempatan yang sama untuk melakukan bisnis tanpa harus memerlukan modal yang besar. Perubahan fisik pada ruang dalam terlihat pada perubahan fungsi, perubahan volume ruang, pertumbuhan dan pembagian ruang, penataan ruang, serta perubahan zonasi ruang.

Pada era belanja online, perubahan kegiatan mereduksi peran ruang display dan menambah ruang penyimpanan barang. Meningkatnya permintaan barang secara online, mendorong perluasan ruang produksi. Pengurangan ruang display dan rak merupakan bukti konkrit dari perubahan pola kegiatan dalam memajang produk yang dijual. Penambahan ruang penyimpanan barang khusus diperuntukkan bagi barang-barang yang sudah dikemas dan siap dikirimkan ke konsumen yang telah memesan barang. Sementara itu, perluasan ruang produksi dan penambahan mesin produksi dilakukan untuk memenuhi peningkatan permintaan produksi barang yang dipesan secara online. Produksi secara besar mendorong perubahan ruang produksi lebih teratur untuk mempermudah proses produksi dengan baik.

Perubahan kegiatan ini juga mendorong adanya kebutuhan ruang administrasi dan ruang packing khusus. Kebutuhan akan ruang administrasi muncul untuk mencetak daftar data pesanan dan pesanan sesuai permintaan konsumen (pre-order). Barang yang telah diproduksi kemudian dikemas pada ruang khusus packing. Pengemasan barang yang banyak menuntut adanya ruang khusus yang difungsikan untuk mengemas barang-barang yang dipesan.

Lebih lanjut, perubahan zona ruang ditemukan seiring dengan perubahan fungsi ruang. Perubahan/pengurangan ruang display menjadi ruang produksi menyebabkan perubahan zona ruang dari publik ke servis. Sementara itu, perluasan ruang produksi menggeser zona privat menjadi zona servis. Kecenderungan pergeseran ruang privat-publik menjadi 
ruang servis dikarenakan ekspansi ruang produksi yang lebih luas. Hasil penelitian ini dapat digunakan sebagai acuan bagi arsitek maupun pengembang perumahan untuk mempertimbangkan penambahan kebutuhan masyarakat di era Industri 4.0 dalam perancangan perumahan dan permukiman.

Dalam konteks yang lebih luas, penetapan Kelurahan Cibaduyut sebagai area industri kreatif harus memanfaatkan peluang perkembangan teknologi dan informasi untuk meningkatkan kualitas hidup penduduk. Pada penelitian sebelumnya, Lin (2018) menyarankan pengembangan e-commerce dalam satu tempat harus diiringi dengan penyediaan infrastruktur teknologi informasi dan teknologi mengingat online shop dioperasikan melalui mobile apps dan website. pengembangan tersebut sebaiknya mempertimbangkan toko konvensional, sistem layanan, dan pengaturan geografis. pertimbangan tersebut merujuk pada jarak pasar grosir dan area produksi, kemudahan aksesibilitas transportasi umum, dan sistem logistik yang terintegrasi dengan layanan yang murah.

Penelitian lebih lanjut seharusnya dilakukan dengan mempertimbangkan keterbatasan penelitian dalam mengambil jumlah sampel yang lebih banyak. Selain itu, penelitian pada subjek pebisnis online yang telah menjalankan bisnis online sebagai bisnis utama (bisnis konvensional hanya sebagai pendukung) perlu dilakukan. Hal ini bertujuan agar transformasi rumah tinggal yang terjadi lebih terlihat dengan jelas. Selain itu, keberagaman produk yang dijual, jenis online shop (Dewi \& Soesanto, 2005), serta ukuran, kualitas, dan kompleksitas produk (Douglas, 2006) juga menjadi pertimbangan dalam penelitian selanjutnya dalam meninjau perubahan karakteristik fisik ruang.

\section{UCAPAN TERIMA KASIH}

Peneliti mengucapkan terima kasih atas masukan dan saran dari penelaah (anonymous reviewer) yang membantu peneliti menyusun artikel lebih baik secara substansi maupun referensi.

\section{Daftar Pustaka}

Burke, R. R. (2001). Technology and the Customer Interface: What Consumers Want in the Physical and Virtual Store. Journal of the Academy of Marketing Science, 30(4), 411-432. https://doi.org/10.1177/009207002236914

Chan, X., Bin, L., \& Tianzuo, W. (2017). New Patterns of County In-Situ Urbanization and Rural Development: Perspective of E-Commerce. China City Planning Review, 26(4), 34-41.

Chidambaram, L., \& Zigurs, I. (2001). Our Virtual World: The Transformation of Work, Play and Life via Technology (Vol. 18). Idea Group Publishing.
Dewi, A., \& Soesanto, antariksa san. (2005). Pengaruh Kegiatan Berdagang Terhadap Pola Ruang Dalam Bangunan Rumah-Toko Kawasan Pecinan Kota Malang. Dimensi Teknik Arsitektur, 33(1), 17-26.

Douglas, J. (2006). Building Adaptation. Routledge.

Erdiono, D., Karongkong, H. H., \& Direga, F. O. P. (2012). Studi Pengamatan terjadinya Pola Pergeseran Fungsi Ruang pada Bangunan RumahToko di Manado. Media Matrasain, 9(3), 47-66.

Freathy, P., \& Calderwood, E. (2020). Social transformation in the Scottish islands: Liberationist perspectives on consumer empowerment. Journal of Rural Studies, 1-10. https://doi.org/10.1016/j.jrurstud.2020.01.016

Herdiansyah, A. (2016). Kajian Transformasi Bentuk dan Fungsi pada Perumnas Type 36 di Area Kampus Universitas Islam Riau Pekanbaru.

Kellett, P., \& Tipple, G. (2002). Home-Based Enterprise and Housing Policy: Evidence from India and Indonesia. ENHR 2002, 1-5.

Kumar, R. (2005). Research Methodology: A Step-bystep Guide for Beginners (2nd Editio). SAGE Publication Ltd.

Lin, Y. (2018). E-urbanism: E-commerce, migration, and the transformation of Taobao villages in urban China. Cities, 1-11. https://doi.org/10.1016/j.cities.2018.11.020

Marlina, R. (2018). Pembagian Zona Dalam Sebuah Ruang. $\quad$ Verdant.Id. https://verdant.id/artikel/pembagian-zona-dalamsebuah-ruangan/

Mosconi, F. (2015). The new European industrial policy: Global competitiveness and the manufacturing renaissance. Routledge.

Omar, E. O., Endut, E., \& Saruwono, M. (2017). Adapting by Altering: Spatial modifications of terraced houses in the Klang Valley area. Asian Journal of Environment-Behaviour Studies, 2(2), 1-10. https://doi.org/10.21834/aje-bs.v2i2.173

Prasetyo, B., \& Trisyanti, U. (2018). Revolusi Industri 4.0 dan Tantangan Perubahan Sosial. Prosiding SEMATEKSOS 3: Strategi Pembangunan Nasional Menghadapi Revolusi Industri 4.0, 2227.

Pujantara, R. (2014). Karakteristik Ruang pada Rancangan Arsitektur dengan Konsep Superimposisi dan Hibrid dalam Teori Function Follow Form. Jurnal Forum Bangunan, 12(1), 1825.

Purnamasari, L. S., Antariksa, \& Suryasari, N. (2010). Pola Tata Ruang Dalam Rumah Tinggal Masa Kolonial di Kidul Dalem Malang. Aristektue EJournal UB, 3(1), 40-53.

Roblek, V., Meško, M., \& Krapež, A. (2016). A Complex View of Industry 4 . 0. Sage Open, 6(2), 
1-11. https://doi.org/10.1177/2158244016653987

Soegiono, B. S., Setijanti, P., \& Faqih, M. (2011). Transformasi Penggunaan Ruang Hunian Akibat Usaha berbasis Rumah Tangga Studi Kasus: Pengrajin Seni Ukir Batu Dusun Jatisumber Desa Watesumpak Kecamatan Trowulan Kabupaten Mojokerto. In Digilib ITS.

Watson, P. (2009). The key issues when choosing adaptation of an existing building over new build. Journal of Building Appraisal, 4(3), 215-223. https://doi.org/10.1057/jba.2008.39

Wibisono, I. (2013). Tingkat dan Jenis Perubahan Fisik Ruang Dalam Pada Rumah Produktif (UBR) Perajin Tempe Kampung Sanan, Malang. Jurnal RUAS, 11(2), 75-88. 